\title{
A NEW LOCATION FOR PERIPATUS IN JAMAICA
}

\author{
W. GARDNER LYNN \\ The Johns Hopkins University
}

The Island of Jamaica, B. W. I., is the habitat of two members of the Onychophora one of which, Peripatus swainsonæ Cockerell, is an endemic species, while the other, Plicatoperipatus jamaicensis (Grabham and Cockerell), is the sole representative of an endemic sub-genus. The history of the discovery of these animals and the facts as to their known distribution in Jamaica have recently been reviewed by E. A. Andrews (1933) and will be only briefly summarized here. The first recorded specimens from the island were collected by Philip Henry Gosse (1851) at Bluefields in the southwestern part of Jamaica, but were not at that time described as new. Forty years later (Grabham and Cockerell, 1892) Peripatus was again reported from Jamaica but from quite a different locality, near Bath in the southeastern portion of the island. These specimens were assigned to a new series. Peripatus jamaicensis, and Gosse's original collections were assumed to represent the same. During the succeeding years several hundreds of specimens were obtained from the Bath region and when critically examined by Bouvier they were found to belong to two distinct species. Peripatus jamaicensis was present in considerable numbers but the majority of the specimens were regarded as representing a new variety of the species Peripatus juliformis Guilding which received the name $P$. juliformis var. swainson $\mathscr{X}$ Cockerell and is so designated in Bouvier's (1905) monograph of the group. Gosse's original collection, of which three specimens were still extant in the British Museum, was also found to contain representatives of both these forms. Later in Clark's (1913) revision of the American species of Peripatus, a new sub-genus, Plicatoperipatus, was erected for the reception of the species $P$. jamaicensis and the variety 
swainsonæ was elevated to specific rank under Peripatus $s$. $s$. In the time which has elapsed since the discovery of Peripatus at Bath, single specimens have been found at three other widely separated localities on the island. F. S. Conant collected an example of $P$. jamaicensis at Blue Hole near Port Antonio on the north coast in the summer of 1897 ; E. A. Andrews found P. swainsonæ near the Great River east of Montego Bay in 1910 and again at a locality very near Kingston, above Constant Springs, in 1932. All three of these specimens are to be found in the museum collection of the Johns Hopkins University. Peripatus has thus far been taken at five widely separated points in Jamaica which, if connected by straight lines, would surround

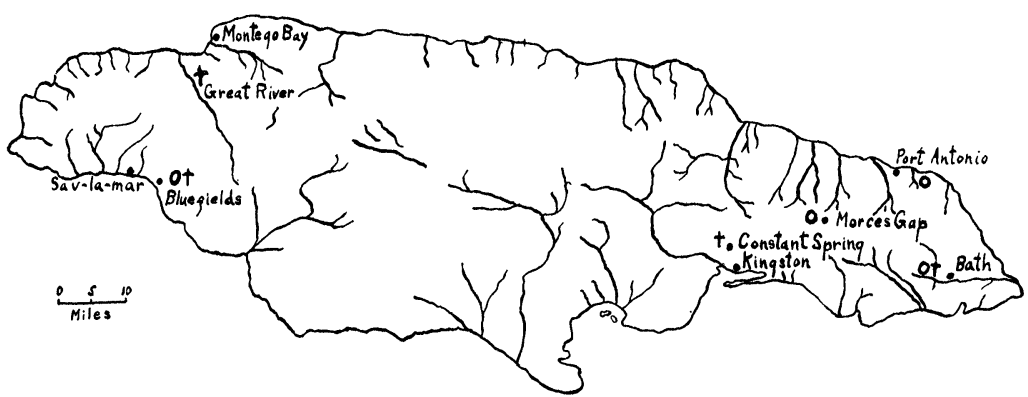

Figure 1-Outline map of Jamaica showing the six known localities for the Onychophora in that island. $+=$ Peripatus swainsonae; $\mathrm{O}=$ Plicatoperipatus jamaicensis.

an area embracing more than half the island. However, as Andrews points out, it is by no means certain that the animal occurs in all or much of this intermediate area. All five of the known localities are at relatively low altitudes, 1,000 feet or less, and the presence of Peripatus in the central mountain chain with its highest peaks rising to over 7,000 feet, has remained to be established.

It was therefore with great interest that the writer, during the past summer, came upon Peripatus in the heart of the Blue Mountains at an altitude of nearly 5,000 feet. While collecting the eggs of the toad Eleutherodactylus nubicola (in connection with an embryological study aided by a grant from the National Research Council) a speci- 
men of Plicatoperipatus jamaicensis was found beneath a rock near Morce's Gap. This gap is located between John Crow Peak and Bellevue Peak in the Parish of Portland at an elevation of 4,980 feet. It is but two miles north of the Cinchona plantation and through it passes the trail which leads from Silver Hill to Orange Bay. It is located in the region of perpetual rain-forest with an annual rainfall of 105.70 inches (Shreve, 1914). The specimen herein described was found only about one hundred yards from the gap, beside the trail which leads to Trafalgar Gap, the "Vinegar Hill Trail." Upon turning a rock the animal was seen crawling about slowly on a bare stone in the neighborhood of a few dead leaves. The ground was somewhat dry at this time, there having been no rain for several days. The specimen was induced to crawl upon a leaf and was then placed in an $8 \mathrm{oz}$. collecting jar without handling. However, when a portion of the animal's skin touched the collecting bottle a whitish substance was given off at the point of contact and two large drops also appeared at the openings of the mucous glands on the oral papillæ. An examination of the bottle revealed that it was one in which an alcoholic specimen had previously been kept and that it still retained a slight trace of alcohol odor. The Peripatus was immediately transferred to a clean bottle in which it was carried without harm for the rest of the day. The portion of the body which had come into contact with the wall of the first bottle formed a whitish blister-like swelling, however, which may be seen in the photographs (Fig. 2) and still remains in the preserved specimen. The animal was collected at about 2 P.M. on July 21 . It was carried about during the rest of the day's collecting and was successfully transported to Chester Vale, some three miles distant, where it was photographed the same afternoon. It was kept in a large jar with a plentiful supply of dead leaves, the jar being wrapped in a moist cloth to give coolness and darkness. Here it remained quite active, moving about among the leaves and seemingly carrying on a normal existence. On July 27 it was preserved in Bouin's Fluid for sectioning. Before being preserved it was killed by exposure to the fumes of chloroform. At this time it 
threw out its viscid white mucous from the oral papillæ to a distance of three inches and several thread-like strands of the substance also appeared from the posterior mucous glands. It had not been seen to do this during the week it

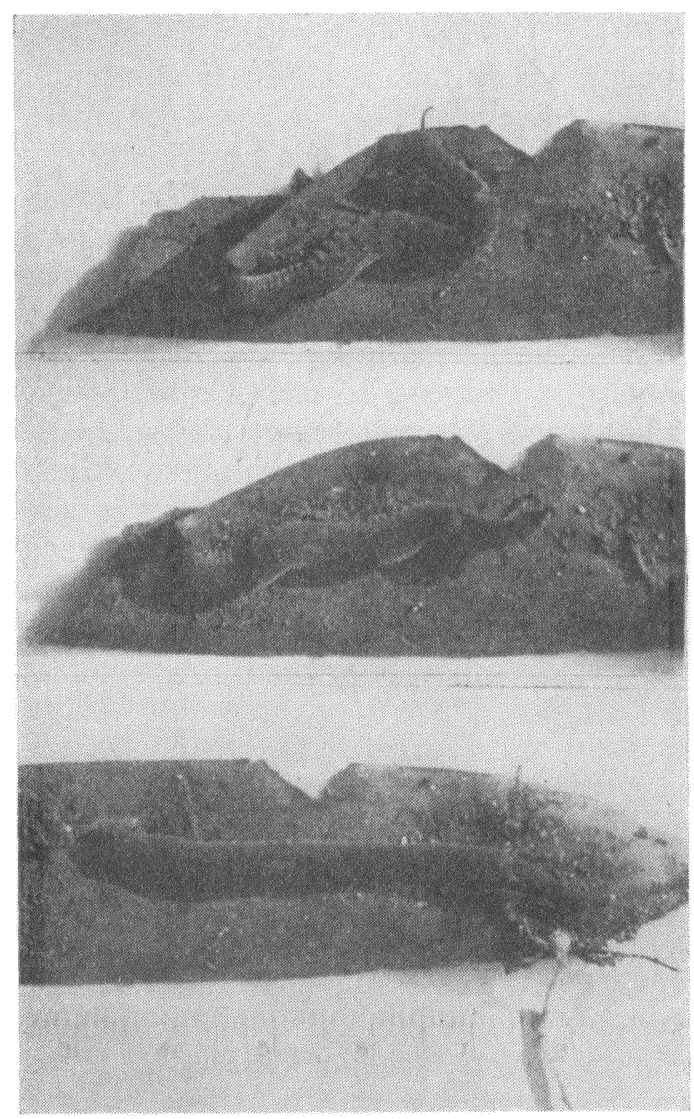

Figure 2. Three successive photographs of Plicatoperipatus jamaicensis crawling upon a leaf. Metric beneath lower figure.

was under observation which may lead to the conclusion that it did not feed, since Mme. Claude-Joseph (1928) describes the use of this substance in the capture of prey. When the specimen was immersed in Bouin's solution it was 
found to be completely coated dorsally by a thin film of air and it was only when warm Bouin's was employed that a proper preservation was insured. The power of the skin of Peripatus to repel moisture by means of the coating of air which forms about the papillæ has frequently been noted (Claude-Joseph 1928, Andrews 1933). During life the animal was dark reddish-brown above and pinkish beneath; the papillæ appearing as an obscure peppering of light spots over the whole surface, with however some indication of an arrangement in four longitudinal rows on the dorsal side. Faint light stripes encircled the body opposite each pair of legs. The antennæ were brown with striking white tips (Fig. 2, lower photo) and were constantly moving about in all directions, sometimes even crossing each other. The body was $61 \mathrm{~mm}$. long when extended; the antennæ about $5 \mathrm{~mm}$. As preserved the body is contracted to $45 \mathrm{~mm}$. and the antennæ to $3 \mathrm{~mm}$. The individual is a female and has 38 pairs of legs. Only this one specimen was found even though much time was spent during June and July in turning rocks in this same general locality while collecting frog eggs. Possibly, however, a search in dead trees and logs would have revealed more specimens. Mme. Claude-Joseph found the Chilean species Opisthopatus (Metaperipatus) blainvillei quite commonly under the bark of dead tree trunks though it occurred only very rarely beneath stones and logs.

This sixth locality for Peripatus in Jamaica seems especially worthy of note since it lies within the area surrounded by the other known regions where Peripatus occurs, and in the heart of the Blue Mountains almost exactly mid-way between the north and south coasts. This apparently constitutes the first record of any member of the Onychopora from the Blue Mountain Range proper. Gosse's place of original discovery, Bluefields, is some eighty miles from the nearest part of the Blue Mountain chain and the three localities reported by Andrews (1911, 1933) are all in the lowlands near the coast. The Bath region lies in the foothills of the extreme eastern end of the Blue Mountain chain. In this connection attention may be called to a recent statement by Dr. C. T. Brues (1935) to 
the effect that "The occurence of Onychophora in Jamaica is, however, so far as known, restricted to the Blue Mountains as none have been discovered in other parts of the island." Possibly this error is based upon a misunderstanding as to the locality of Bluefields, which in spite of the name is far distant from the Blue Mountains.

The great altitudinal range of Plicatoperipatus jamaicensis revealed by the present record is noteworthy. Unfortunately exact altitude records have not been given for most of the 60 or 70 described species of Peripatus. The greatest elevation reached by any species seems to be that attained by Paraperipatus lorenzi Horst which was reported from the Wichmann Mts. of Dutch New Guinea at 10,000 feet. Oroperipatus cameranoi (Bouvier) was collected in the region of Sigsig and Cuenca, Ecuador at an altitude of 2,550 meters (7,287 feet) and Peripatus manni Brues was recently recorded from near La Vesite, La Salle Plateau, Haiti at 5,000-7,000 feet. Peripatoides (Ooperipatus) oviparus (Dendy) is known from a number of localities in Victoria and New South Wales, Australia and Helms (1890) records it from Mt. Kosciusko in the latter province at an altitude of 5,700 feet, in a region frequently covered with several feet of snow for four or five months in the year. In addition to these Onychophora which are definitely recorded at considerable elevations in various parts of the world it is quite probable that a number of others of the Andean and Australasian forms may have come from comparable altitudes and that a careful check-up of the elevations of all the localities from which they are reported would reveal this. As to the altitudinal distribution of single species, however, less information is available. The present record extends the range of $P$. jamaicensis from sea level (the Blue Hole locality) to 5,000 feet. This range is rivaled by that of another Caribbean form Epiperipatus biolleyi (Bouvier) from Costa Rica which was found by M. P. Biolley near San Matteo at 250 meters and later by Picado at an altitude of 2,000 meters. Other instances of comparable ranges could undoubtedly be culled from the literature. For example Peripatopsis moseleyi WoodMason, which is found at Riet Vlei, Natal, at 5,000 feet has 
also been collected near Port Elisabeth, Cape Colony, a seaport town; Peripatoides oviparus (Dendy) is not only recorded from Mt. Kosciusko but also from Pyalong and Warburton in Victoria, localities for which the International Map of the World shows altitudes of 200-300 meters; Oroperipatus corradoi (Camerano) comes from the Quito plain in Ecuador which is at 9,500 feet altitude but it is also reported from near Guayaquil on the coast. The ability of Peripatus to withstand the great range of conditions to which it must be subjected at these various altitudes would seem to be worthy of consideration in relation to the problem of dispersal of this animal. Also, the fact that individuals showing the same specific characters are found inhabiting such diverse regions may be regarded as further evidence of the very slight tendency towards speciation in this group, which has resulted in its retention of so many primitive characteristics.

\section{LITERATURE CITED}

Andrews, E. A. Jamaica Peripatus. Notes from the J. H. U. Laboratory at Montego Bay, Jamaica, Sumner 1910. Johns Hopkins Univ. Circ. Feb. 1911. pp. 155-163. 1933.

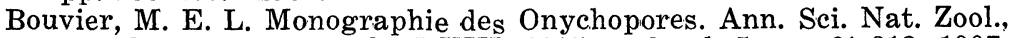
vol. 2, pp. 1-383. pls. I-XIII. 1905. and vol. 5, pp. 61-318. 1907.

Brues, C. T. Varietal forms of Peripatus in Haiti. Psyche, vol. 42, pp. 58-62. 1935.

Clark, A. H. A revision of the American species of Peripatus. Proc. Biol. Soc. Wash., vol. 36, pp.15-20. 1913.

Claude-Joseph, Mme. Observations sur Peripate du Chili (Opisthopatus blainvillei Gay-Gervais), Ann. Sci. Nat. Zool. Series 10, vol. $11, \mathrm{pp}$. 285-298. 1928.

Gosse, P. H. A. Naturalist's Sojourn in Jamaica. London 1851.

Grabham, M., \& T. D. A. Cockerell. Peripatus rediscovered in Jamaica. Nature, vol. 46 , p. 514. 1892.

Helms, R. Report of a collecting trip to Mount Kosciusko. Rec. Austral. Mus., vol. 1 pp. 11-16. 1890.

Shreve, Forrest. A Montane Rrin-Forest. Carnegie Inst., Washington, Publ. No. 199, pp. 1-110. 1914. 

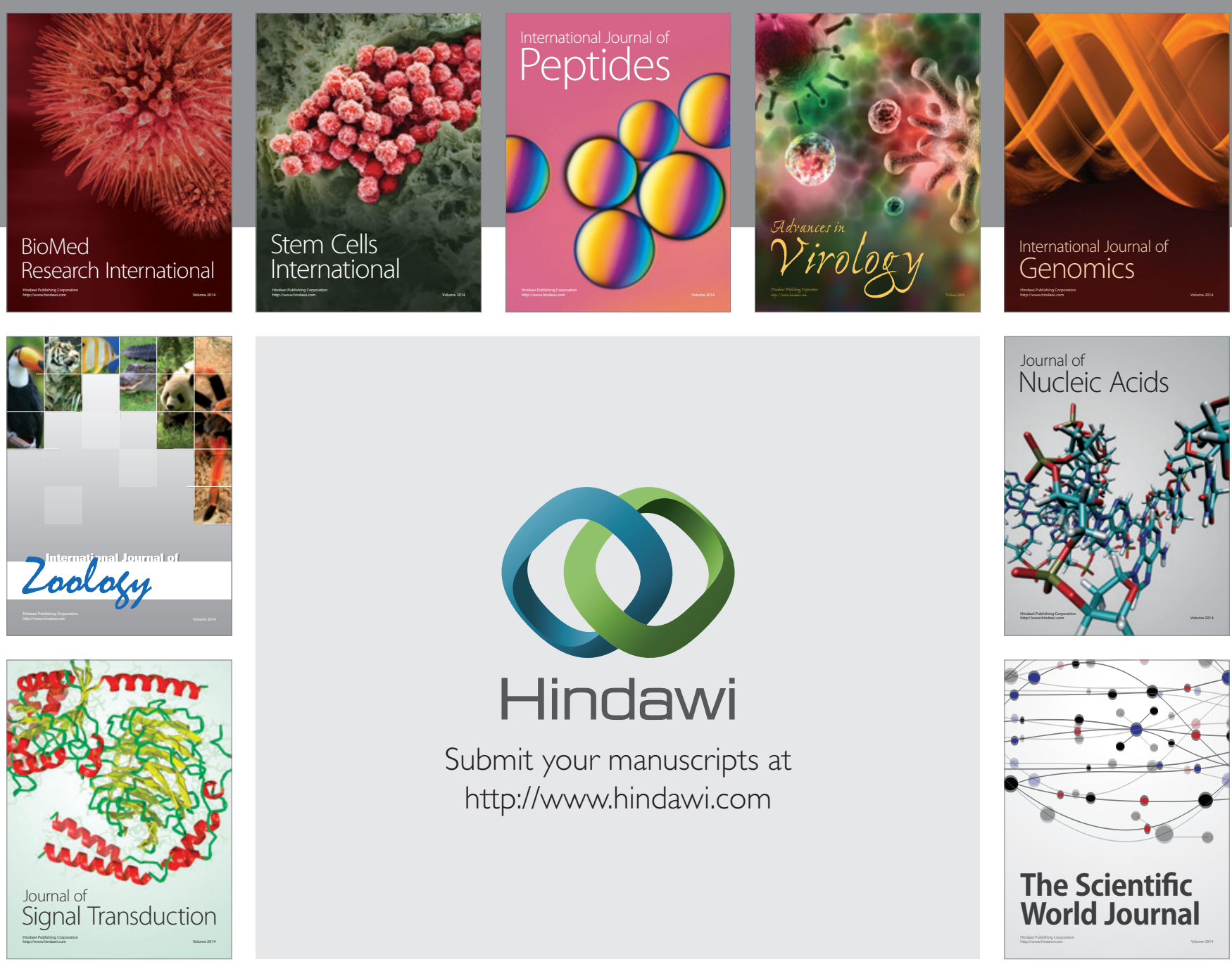

Submit your manuscripts at

http://www.hindawi.com
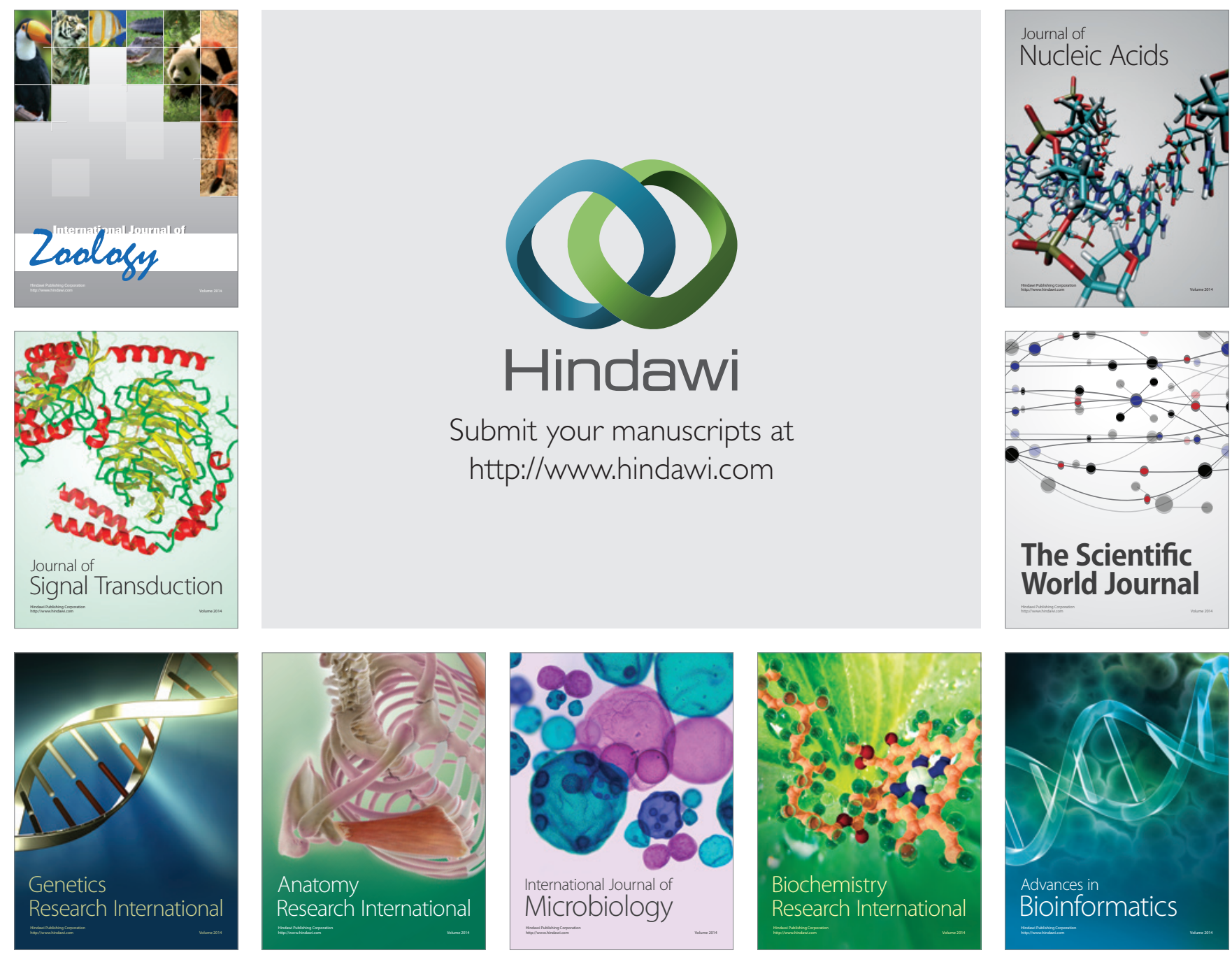

The Scientific World Journal
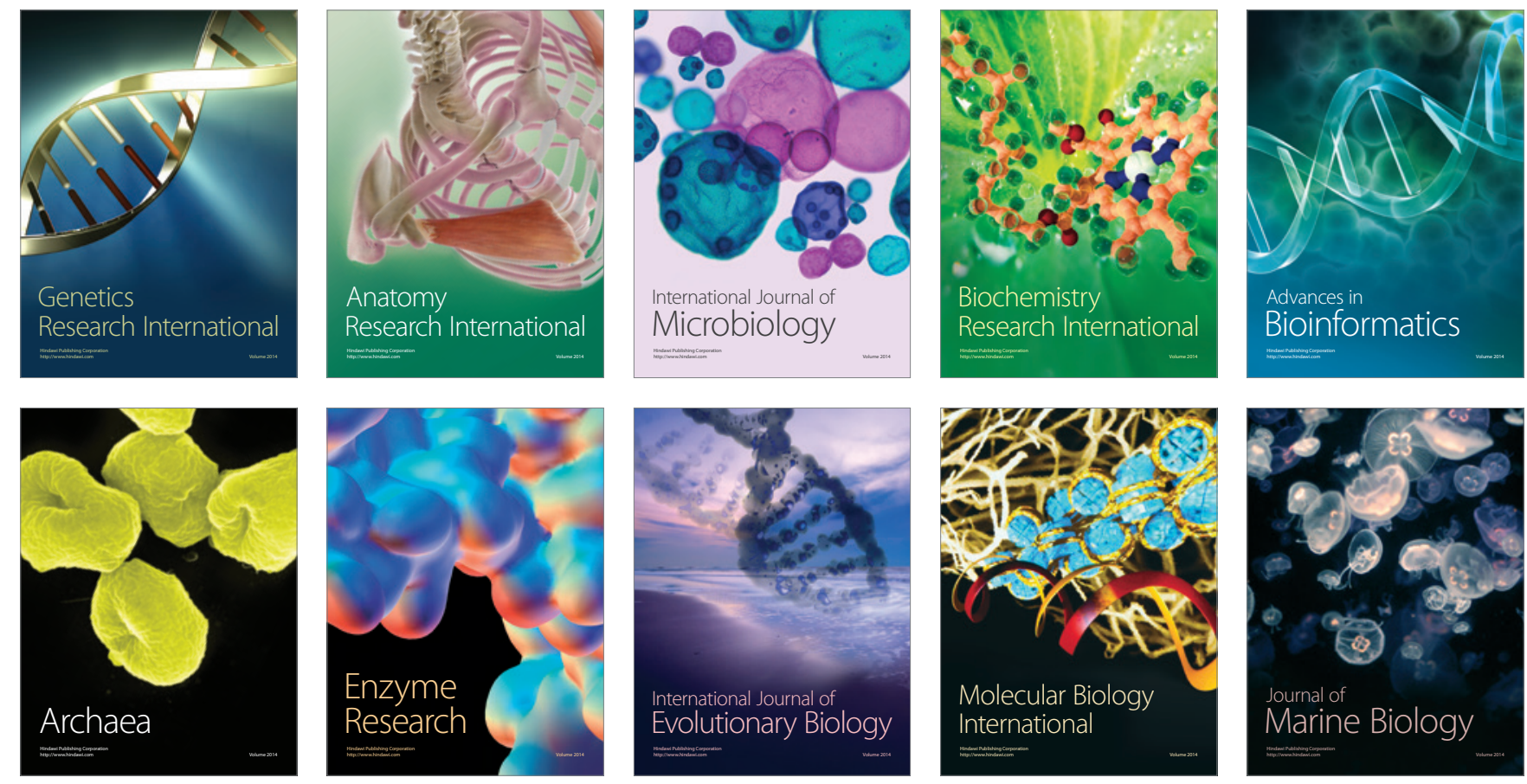